\title{
ERRATUM
}

\section{HISTOPHYSICS: A NEW DISCIPLINE}

\author{
[Mod. Phys. Lett. B, Vol. 16, No. 30 (2002) 1163-1176]
}

LUI LAM

On p. 1165, line 12:

'It is "easy" for present historians to second guess the works of past historians.' should read as:

'It is "easy" for present historians to second guess the acts of past historian players.' And line 13:

'The size of a water molecule is very small, about 10-8 centimeter ...' should read as:

'The size of a water molecule is very small, about $10^{-8}$ centimeter ...'

The correct year of publication for Ref. 6 is 1998, while the correct year for Ref. 35 is 2003 . 